А. А. Торба, М. О. Торба, О. О. Торба

\title{
РАДІОЧАСТОТНІ КОМПЛЕКСИ ВИЯВЛЕННЯ МАЛОРОЗМІРНИХ БЕЗПІЛОТНИХ ЛІТАЛЬНИХ АПАРАТІВ
}

\begin{abstract}
Анотація: Завдання виявлення малорозмірних безпілотних літальних апаратів ускладнюється з причини їх малих габаритів, вживанню композитних матеріалів корпусів, що не відбивають радіохвилі РЛС і мінімальному тепловому випромінюванню. Найбільшу уразливість обумовлює наявність у них джерел електромагнітного випромінювання для передачі в реальному часі команд і обміну розвідувальною інформацією, у тому числі сигналами для передачі в реальному часі телевізійних зображень. Метою роботи є розробка технічних параметрів радіотехнічних комплексів для моніторингу електромагнітних випромінювань малорозмірних безпілотних літальних апаратів в радіочастотному, інфрачервоному та оптичному діапазонах і пеленгації джерел цих випромінювань 3 метою їх перехоплення, придушення або знищення. У роботі проведено аналіз методів виявлення малорозмірних безпілотних літальних апаратів в радіочастотному діапазоні. Зроблено висновок про доцільність використання пошукових методів по частоті і безпошукових методів виявлення по напряму. Запропонована структура радіочастотного комплексу виявлення малорозмірних безпілотних літальних апаратів. Розроблені макет одного каналу з пошуком сигналів по частоті та алгоритми первинної обробки радіосигналів, відображення результатів обробки сигналів у вигляді спектрограми та вводу цих результатів у комп'ютері.
\end{abstract}

Ключов і слов а: малорозмірні безпілотні літальні апарати (МБПЛА), радіомоніторинг, мікроконтролер, радіоприймальний модуль, комп'ютер, імовірність виявлення радіовипромінювань МБПЛА.

\section{Вступ}

Значення безпілотних літальних апаратів (БПЛА), що зростає з кожним роком, сприяє безперервним роботам по іх удосконаленню. Нові завдання, поліпшення тактико-технічних характеристик БПЛА, у тому числі, зменшення їх розмірів, ускладнює задачу по їх виявленню. У зв'язку з чим, виявлення малорозмірних безпілотних літальних апаратів (МБПЛА) є пріоритетним завданням при створенні систем по протидії БПЛА.

Метою роботи є розробка технічних параметрів радіотехнічних комплексів для моніторингу електромагнітних випромінювань малорозмірних безпілотних літальних апаратів в радіочастотному, інфрачервоному та оптичному діапазонах і пеленгації джерел цих випромінювань 3 метою їх перехоплення, придушення або знищення.

\section{1. Класифікація БПЛА}

Відповідно до існуючої класифікації БПЛА за їх основними характеристиками, вони поділяються на дві групи: (МБЛА);

- малорозмірні безпілотні літальні апарати

- БПЛА середніх і великих розмірів.

Боротьба з МБЛА $є$ комплексом заходів по їх виявленню, розпізнаванню, прицілюванню і поразці. У зв'язку з малою помітністю МБЛА завдання по виявленню і розпізнаванню цих апаратів $\epsilon$ найбільш складним і важливим.

Класифікація МБЛА за розмірами та масою [13]:

- нано-БЛА масою менш одного кілограма, тривалістю польоту менш однієї години і висотою польоту до 300 м;

- мікро-БЛА - масою до 10 кг, часом польоту біля однієї години і висотою польоту до 1000 м;

- міні-БЛА - масою до 50 кг, часом польоту до декількох годин і висотою польоту до 3000 $5000 \mathrm{M.}$

\section{2. Огляд існуючих методів виявлення МБПЛА на основі аналізу електромагнітного спектру}

Сучасні легкі МБЛА роблять 3 композитних матеріалів і пластика із спеціальним фарбуванням і 3 особливою комбінацією шарів. Їх невеликі бензинові $\mathrm{i}$, тим більше, електричні двигуни мало випромінюють тепло і працюють майже безшумно. Тому для ефективного виконання завдання виявлення МБЛА необхідне одночасне використання декількох методів. Найбільша уразливість МБЛА обумовлюється наявністю у них джерел електромагнітного випромінювання (ЕМВ). До демаскуючих ЕМВ відносяться: сигнали бортового відповідача; команди і «доповіді» каналу управління між наземним пунктом управління i МБЛА, а також між МБЛА і супутником-ретранслятором системи навігації; сигнали бортової РЛС бічного огляду; канали обміну розвідувальною інформацією, у тому числі сигнали телевізійних зображень, що передаються в реальному часі; сигнали системи автоматичної посадки на аеродром.

Основними радіотехнічними засобами виявлення МБЛА в електромагнітному спектрі $є$ [1-3]: використання тепловізора інфрачервоного діапазону ЕМ хвиль; використання камер оптичного діапазону ЕМ хвиль; використання радіолокаційних станцій; здійснення радіомоніторингу і пеленгування напряму на джерело ЕМ випромінювання.

Для виявлення об'єктів з температурою, що відрізняється від довкілля, використовуються інфрачервоні тепловізійні камери. Це дозволяє вести спостереження за МБЛА навіть в умовах обмеженої видимості і в темний час доби.

Для здобуття найбільш інформативних і надійних результатів можливе точне наведення і поєднання зображень телевізійних камер по тепловізійним зображенням.

Використання для виявлення безпілотних літальних апаратів методів радіолокації є складним завданням для існуючих РЛС. МБЛА мають малу 
ефективну площу розсіяння (ЕПР), через що їх виявлення стає досить складним завданням. Зокрема, знижується максимальна дальність виявлення.

Радіомоніторинг - $\epsilon$ метод отримання інформації з використанням технічних засобів на ділянці їі проходження по лініях радіозв'язку.

Завданнями радіомоніторингу ефіру є:

- панорамний спектральний аналіз у реальному часі;

- ошук випромінювань від БПЛА або інших об’єктів, вимір їх параметрів та селекція сигналів від сторонніх джерел випромінювання,

- порівняння з базою даних для визначення їх приналежності;

- запис радіосигналів із службовими параметрами (частота, час, рівень сигналу, спектрограма і т. п.) і подальше їх відтворення;

- технічний аналіз радіосигналів в реальному часі і при відкладеній обробці;

- визначення напряму на БПЛА (пеленгація).

\section{3. Комплексне використання заходів для виявлення МБЛА}

Найбільш ефективним рішенням $є$ комбінування основних способів виявлення: застосування засобів радіолокації, використання радіомоніторингу, використання інфрачервоних і оптичних відеокамер.

Незважаючи на значні матеріальні витрати, кожен 3 цих методів доповнює інший, i, таким чином, зменшується кількість неправдивих виявлень і збільшується загальна ефективність системи - збільшується імовірність виявлення МБЛА на достатній відстані для його перехоплення або знешкодження.

Радар сантиметрового або міліметрового діапазону хвиль виявляє МБПЛА, паралельно з цим устаткування радіомоніторингу приймає сигнали в заданих діапазонах радіочастотних випромінювань, i шукає серед них підозрілі, далі інфрачервоні та відеокамери наводяться на вірогідний об'єкт виявлення, і приймається рішення про передачу команди на придушення, перехоплення або знищення виявлених об'єктів. Комплекс із засобами радіомоніторингу виконує завдання виявлення передавачів, встановлених на БПЛА, визначення їх типа і основних характеристик (ідентифікацію) та збору інформації для здійснення перехоплення управління.

Вибір методу радіомоніторингу - пошукового або безпошукового - $\epsilon$ компромісом між зменшенням імовірності пропуску сигналу і дальністю виявлення мети (при допустимих економічних витратах).

У безпошукових засобів виявлення по частоті у всьому діапазоні спостереження $€$ широкі смуги пропускання сигналу i, як наслідок, збільшений рівень шумів (завад). Це зменшує чутливість радіоприймальних пристроїв систем радіомоніторингу, обмежену шумами, і зменшує дальність виявлення радіовипромінювань БПЛА. Пошукові системи радіомоніторингу по частоті мають невелику смугу пропускання, яка може оперативно змінюватися залежно від завдань пошуку радіосигналів конкретних радіопередавальних пристроїв. Такі системи мають найкращу чутливість, обмежену шумами, i максимальну дальність виявлення об'єктів.

Недоліком пошукових систем по частоті $є$ підвищена імовірність пропуску коротких сигналів, які випромінюють БПЛА.

Окрім пошуку по частоті обов'язковим засобом виявлення БПЛА $є$ просторова селекція прийнятих радіосигналів для визначення напряму на об'єкт загрози (пеленгація радіопередавальних пристроїв БПЛА та радіопередавачів їх керування).

Використання безпошукових антенних систем 3 широкою діаграмою спрямованості робить неможливою пеленгацію джерел радіовипромінювань, а також супроводжується зменшенням коефіцієнта підсилення антени i, як наслідок, зменшенням дальності виявлення об'єктів загроз в порівнянні з вузьконаправленими антенами.

Як правило, в системах радіомоніторингу з одночасним пошуком по частоті і по напряму (за допомогою керованих фазованих антенних грат ФАГ) збільшується імовірність пропуску сигналу.

Тому прийнятним компромісом $є$ пошук по частоті і багатоканальна система 3 декількома антенами і радіоприймальними модулями для паралельного виявлення сигналів 3 декількох напрямів по азимуту і по куту місця (рис. 1).

Ширина діаграми спрямованості антени в кожному каналі визначається необхідною точністю визначення напряму на джерело радіовипромінювання. Кількість каналів «n» залежить від ширини повного сектора спостереження i ширини діаграми спрямованості кожної антени.

У кожному каналі $\epsilon$ мікроконтролер, який: приймає команди від мінікомп'ютера, формує коди для вибору частоти в синтезаторі радіоприймального модуля, встановлює часові затримки на час завершення перехідних процесів в синтезаторі радіоприймального модуля, приймає і зберігає сигнали 3 виходу радіоприймального модуля для кожної частоти прийнятого сигналу, проводить первинну обробку прийнятих сигналів, передає в мінікомп'ютер результати радіочастотного сканування всього частотного діапазону. Завдяки тому, що комплекс складається 3 блоків (каналів), можливе створення (конструювання) необхідної конфігурації для специфіки виконання конкретного завдання.

Мінікомп'ютер (або ноутбук) проводить обробку результатів радіочастотного сканування для кожного каналу напряму.

Після отримання результатів радіочастотного сканування всього частотного діапазону виявляє частоти спектра 3 максимальними прийнятими рівнями сигналів, порівнює їх 3 рівнями сигналів для тих же частот у сусідніх каналах напряму для розрахунку уточненого пеленгу на радіопередавальний пристрій МБПЛА. Враховуючи жорсткі міжнародні вимоги по електромагнітній сумісності і усуненню взаємних радіоперешкод, - радіочастотний обмін між МБПЛА і оператором здійснюється в більшості випадків в діапазонах частот для промислової, наукової і медичної апаратури - Industrial, Scientific and Medical band (ISM діапазонах). 


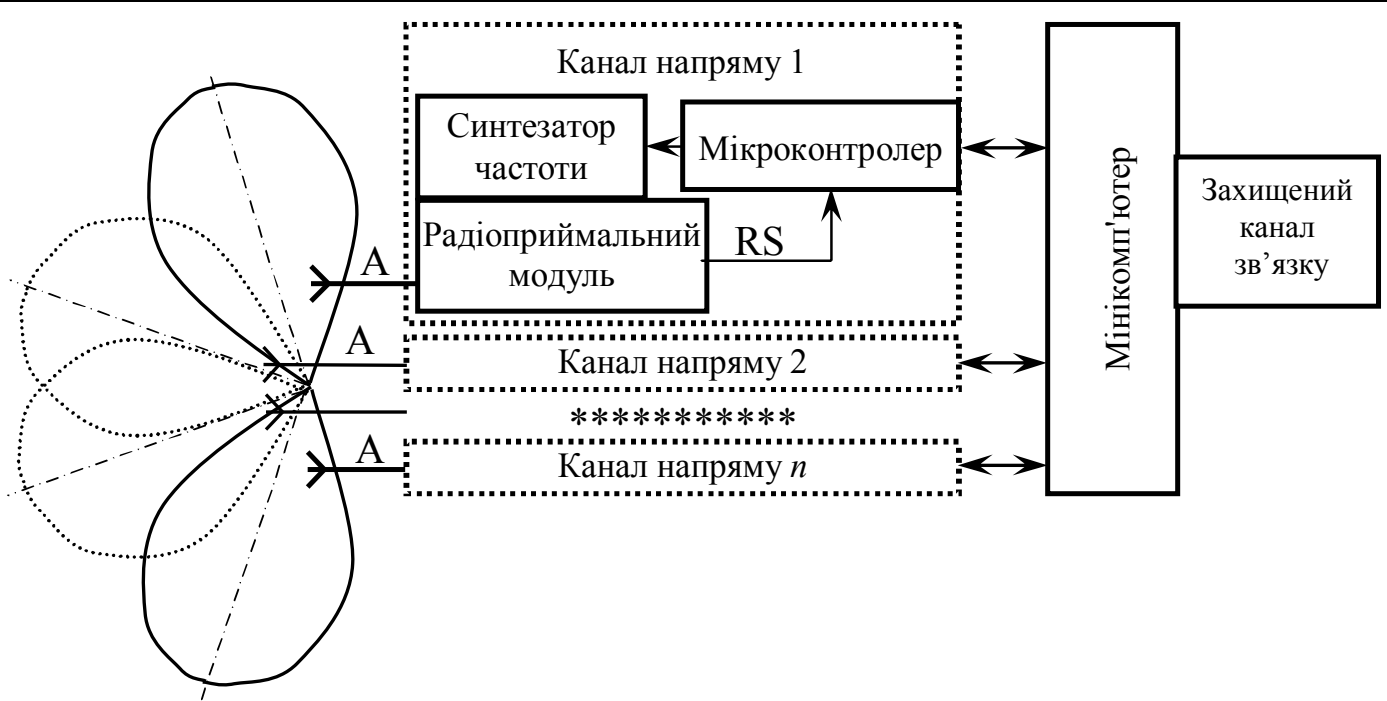

Рис. 1. Комплекс моніторингу радіовипромінювань по частоті і по напряму

Радіопередавальні пристрої в цих діапазонах можливо використовувати без державного ліцензування, якщо дотримуватимуться норми, встановлені регулюючими органами для цієї частині радіочастотного спектру (табл. 1).

Для кожного ISM діапазону необхідно створювати окремий комплекс моніторингу радіовипромінювань по частоті і по напряму (див. рис. 1), оскільки універсальні антенні системи і універсальні радіоприймальні модулі не забезпечують найкращі параметри для кожного діапазону.

Таблиия 1 - Частоти ISM діапазонів

\begin{tabular}{|c|c|c|}
\hline Частота, МГц & $\begin{array}{c}\text { Ширина } \\
\text { діапаз., МГц }\end{array}$ & $\begin{array}{c}\text { Макс. потуж- } \\
\text { ність, мВт }\end{array}$ \\
\hline 2400 & 85 & 100 \\
\hline 5000 & 100 & 200 \\
\hline 5800 & 350 & 500 \\
\hline
\end{tabular}

Центральним вузлом функціонування інтегрованої системи протидії БПЛА, на яку безперервно в автоматичному режимі по захищеним каналам зв'язку приходить вся оброблена інформація від окремих комплексів (див. рис 1), є комп'ютер зі встановленим на ньому спеціальним програмним забезпеченням, здатним приймати рішення в автоматичному режимі.

Варіанти таких рішень:

- передача команди про використання засобів інфрачервоних камер і камер оптичного діапазону для підтвердження виявлення цілей;

- передача команди на уточнення інформації, яка отримана, іншому комплексу, що працює у складі інтегрованої системи протидії БПЛА;

- передача команди на придушення, перехоплення або знищення цілі засобам, що входять до складу системи придушення і знищення БПЛА;

Для контролю за рішеннями, що приймаються інтегрованою системою протидії МБПЛА, і завдання необхідних параметрів - у роботі системи бере участь оператор. Наявність оператора $є$ обов'язковою на етапі наукових досліджень та вибору алгоритмів і параметрів обробки сигналів.

\section{4. Захист каналів зв'язку в системі протидії МБПЛА}

В інтегрованій системі протидії МБПЛА безперервно циркулює великий обсяг інформації, яку треба захищати від перехоплення та зміни. Важливим завданням $\epsilon$ аутентифікація джерел передачі інформації. Авторами запропоновані алгоритми i методи захисту інформації, які реалізуються з мінімальними апаратними затратами $[4,5]$. На одній програмованій логічній інтегральній схемі (ПЛІС) можлива реалізація криптоалгоритмів, які за криптостійкістю не поступаються відомим алгоритмам, що використовуються в системах стільникового зв'язку та інших потокових алгоритмах шифрування. Запропоновані авторами криптоалгоритми захищені патентами України [6- 8].

\section{5. Макетування каналу 3 пошуком сигналів по частоті}

3 метою розробки та дослідження схемотехнічних рішень, розробки та налаштування програмного забезпечення мікроконтролера виготовлен макет каналу радіоприймального пристрою 3 пошуком сигналів по частоті в ISM діапазоні 2,4 ГГц (рис. 2).

Спіральна антена забезпечує прийом радіосигналів 3 вертикальною і горизонтальною поляризацією. Ця вимога обумовлена тим, що МБЛА під час польоту постійно змінює положення у просторі і, як наслідок, змінюється поляризація радіосигналів, що випромінюються

Мікроконтролерна плата ARDUINO MEGA пов'язана 3 радіоприймальним модулем послідовним інтерфейсом SPI.

Легкість програмування плат ARDUINO від ПЕОМ через інтерфейс USB без додаткових програматорів дозволяє змінювати межі діапазонів частот радіоприймального модуля, на програмному рівні змінювати смугу частот радіоприймача, змінювати алгоритми первинної обробки сигналів, налаштовувати параметри алгоритмів, виводити результати обробки сигналів на індикатор, та завантажувати результати у ПЕОМ (ноутбук). 
На рис. 2 (наверху праворуч) наведена спектрограма прийнятих радіосигналів в ISM діапазоні 2,4 ГГц, яка відображається на 3,5 дюймовому TFT екрані з роздільною здатністю 480 на 380 пікселів.

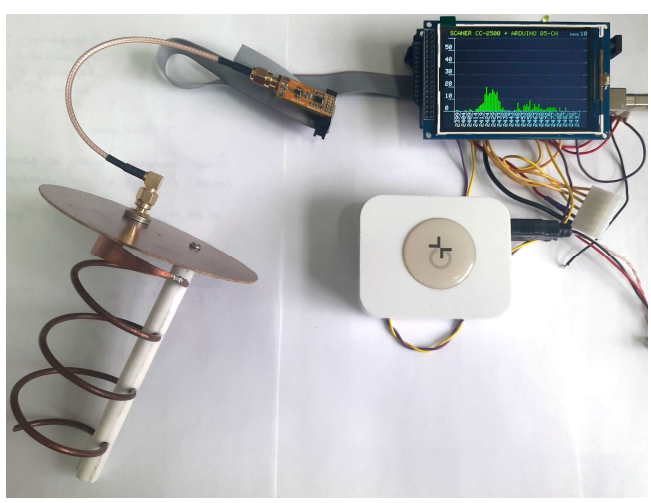

Рис. 2. Макет каналу з пошуком сигналів по частоті

ей екран входить до екосистеми платформи ARDUINO та підключається до процесорної плати через рознімання (без використання паяльників - що дуже важливо на етапі макетування мікроконтролерних систем).

Під час програмування та налагодження програм макет живиться від напруги +5 В інтерфейсу
USB. В «польових умовах» макет живиться від зовнішнього акумулятора Power Bank 3 вихідною напругою +5 В. Енергії акумулятора вистачає для безперервної роботи макета декілька десятків годин.

\section{Висновки}

Завдання виявлення МБЛА ускладнюється 3 причини їх малих габаритів, вживанню композитних матеріалів корпусів, що не відбивають радіохвилі РЛС і мінімальному тепловому випромінюванню.

Найбільшу уразливість МБЛА обумовлює наявність у них джерел електромагнітного випромінювання для передачі в реальному часі команд і обміну розвідувальною інформацією, у тому числі сигналами для передачі в реальному часі телевізійних зображень.

Запропоновано комплекс моніторингу радіовипромінювань МБЛА в межах кожного ISM діапазону 3 пошуком по частоті і багатоканальна система 3 декількома радіоприймальними модулями і вузьконаправленими антенами для пеленгації по напряму.

Розроблені макет одного каналу з пошуком сигналів по частоті та алгоритми первинної обробки радіосигналів, відображення результатів обробки сигналів у вигляді спектрограми та вводу цих результатів у ПЕОМ.

\title{
СПИСОК ЛІТЕРАТУРИ
}

1. Ерёмин Г. В., Гаврилов А. Д., Назарчук И. И. Малоразмерные беспилотники - новая проблема для ПВО // Армейский вестник. 2015. URL:

http://armynews. ru/2015/02/malorazmernye-bespilotniki-novaya-problema-dlya-pvo/

2. Годунов А. И., Шишков С. В., Юрков Н. К. Комплекс обнаружения и борьбы с малогабаритными беспилотными летательными аппаратами // Надежность и качество сложных систем.

3. Филин Е. Д., Киричек Р. В. Методы обнаружения малоразмерных беспилотных летательных аппаратов на основе анализа электромагнитного спектра// Российские беспилотники. 2018. URL: https://russiandrone.ru/ publications/metody-obnaruzheniya-malorazmernykh-bespilotnykh-letatelnykh-apparatov-na-osnove-analiza-elektromagn/

4. Торба А.А. Методы повышения криптостойкости алгоритмов потокового шифрования / А.А. Торба, В.А. Бобух, М.О.Торба, А.О.Торба.- // Радиотехника : Всеукр. межвед. науч.-техн. сб. - 2016. - Вып. 184. - С. 178 - 183.

5. Торба А.А. Детерминированные генераторы псевдослучайных последовательностей для потокового шифрования на основе ДЛРР / А.А. Торба, В.А. Бобух, М.О.Торба, А.О.Торба.- // Научно-технический журнал Прикладная радиоєлектроника. - 2016. - Том 15, № 3.- С.191 - 194.

6. Патент України на корисну модель № 97734, опубл. Бюл. № 7, 2015 г.

7. Патент України на корисну модель № 99194, опубл. Бюл. № 10, 2015 г.

8. Патент України на корисну модель № 115703, опубл. Бюл. № 8, 2017 г.

Received (Надійшла) 20.08.2020

Accepted for publication (Прийнята до друку) 14.10.2020

\section{Radio frequency complexes for detection of small dimensional aircraft}

\author{
A. Torba, M. Torba, O. Torba
}

Abstract: The task of detecting small unmanned aerial vehicles is complicated by their small size, the use of composite materials of the hulls that do not reflect the radio waves of the radar and the minimum thermal radiation. The greatest vulnerability is due to the presence of sources of electromagnetic radiation for the transmission of real-time commands and the exchange of intelligence information, including signals for the transmission of real-time television images. The aim of the work is to develop technical parameters of radio complexes for monitoring electromagnetic radiation of small unmanned aerial vehicles in the radio frequency, infrared and optical ranges and direction finding of sources of these radiation in order to intercept, suppress or destroy them. The paper analyzes the methods of detecting small unmanned aerial vehicles in the radio frequency range. The conclusion on expediency of use of search methods on frequency and searchless methods of detection on a direction is made. The structure of the radio frequency detection complex of small unmanned aerial vehicles is proposed. The layout of one channel with search of signals on frequency and algorithms of primary processing of radio signals, display of results of processing of signals in the form of the spectrogram and input of these results in the computer is developed.

Keywords: small dimensional aircraft, radio monitoring, microcontroller, radio-receiving module, computer, radio monitoring of the small dimensional aircraft radio. 